REVIEW

\title{
Particle aggregation and the biological reactivity of colloids
}

\author{
Paul E. Kepkay \\ Biological Oceanography Division, Biological Sciences Branch, Department of Fisheries and Oceans, Bedford Institute of \\ Oceanography, PO Box 1006, Dartmouth, Nova Scotia, Canada B2Y 4A2
}

\begin{abstract}
The colloidal fraction of dissolved organic carbon in seawater is one of the largest reservoirs of organic carbon on the planet, outweighing phytoplankton or the bacteria by a considerable margin. Even though this colloid-sized material is a carbon reservoir of global significance, it is not easily accessible to the bacteria and may escape extensive biological degradation by virtue of its particle size characteristics. However, when larger colloids (between 0.2 and $2.0 \mu \mathrm{m}$ in diameter) are incorporated into microaggregates (that are tens of $\mu \mathrm{m}$ to $\mathrm{mm}$ across), colloidal organic carbon (COC) is broken down as the aggregates become bioreactors for organic material. For example, the aggregation of colloids and bacteria by surface coagulation triggers a brief ( 2 to $4 \mathrm{~h}$ ) episode of bacterial respiration. The bioreactive nature of aggregates is confirmed in their development as sites of intense bacterial exoenzyme activity, even though the organic material released by this activity remains largely uncoupled from bacterial growth. The degradation of $\mathrm{COC}$ in aggregates is a process that is missing from current models of carbon transport and ocean productivity. In addition, while the COC caught up into aggregates may be more bioreactive than previously suspected, respiration of the aggregated material persists for only a few hours. Realistic measurements of respiration should take this short-lived, but intense, response to aggregation into account.
\end{abstract}

KEY WORDS: Colloids · Aggregation $\cdot$ Respiration $\cdot$ Bacteria

\section{INTRODUCTION}

Colloidal organic carbon (COC) is one of the largest reservoirs of organic carbon on the planet (Cauwet 1978, Hedges 1987, Druffel et al. 1992). It easily outweighs the phytoplankton or bacteria (Cauwet 1978, Druffel et al. 1992; Fig. 1B). Colloidal organic particles (between $1 \mathrm{~nm}$ and a few $\mu \mathrm{m}$ in diameter) are also the most abundant particles in seawater, reaching concentrations as high as $10^{7}$ to $10^{9} \mathrm{ml}^{-1}$ (Koike et al. 1990 , Wells \& Goldberg 1991, 1992, 1994).

In theoretical and laboratory treatments of particle dynamics (Friedlander 1960a, b, McCave 1984, Farley \& Morel 1986, O'Melia 1987, Honeyman \& Santschi 1989, 1992, Santschi \& Honeyman 1991a, b, Johnson \& Kepkay 1992, O'Melia \& Tiller 1993, O'Melia \& Yang 1994), colloid aggregation has been identified as an important mechanism for transferring COC up the particle size spectrum to form microaggregates. These smaller aggregates can then coalesce on a large scale to produce the macroaggregates known as 'marine snow' (Alldredge \& Hartwig 1986).

The settling out of aggregates and copepod fecal pellets have been identified as 2 major routes for the transport of organic carbon from the photic zone to the ocean interior. A number of authors (Honjo 1980, Banse 1990 with references) have reported that most of the material collected by sediment traps is in the form of aggregates rather than fecal pellets. Others (Alldredge et al. 1987, Riebesell 1989 with references) have found the opposite - that fecal pellets are the primary component of material collected by traps. There are 2 reasons why it has been difficult to resolve these conflicting data: (1) fecal pellets settle out 
rapidly, while slower-settling aggregates remain in suspension to at least partially recycle their carbon into the water column; (2) the bioreactivity of aggregates (the rate at which aggregate carbon is broken down and respired to $\mathrm{CO}_{2}$ ) is not well understood.

Johnson \& Kepkay (1992) have suggested that colloid aggregation can accelerate the degradation and respiration of COC. Given the significance of $\mathrm{COC}$ as a global reservoir of carbon, any process that could enhance its reactivity would play a major role in the redefinition of carbon transport and ocean productivity. Nearly all of the results to date suggest that colloid aggregation is indeed an important process (McCave 1984, O'Melia \& Tiller 1993 with references), but it is difficult to utilize existing data sets to establish what might be taking place in the real ocean. Most of these data sets are characterized by adherence to either a biological or physico-chemical viewpoint. Alldredge \& Hartwig (1986) and Johnson et al. (1990) have already outlined the limitations of this partitioned approach to aggregation. They go on to make a point that will be repeated throughout this review - that a combined physical, biological and radiochemical approach is the only viable route to a quantitative understanding of colloid aggregation and its effect on the respiration of COC.

\section{DISSOLVED AND COLLOIDAL ORGANIC CARBON}

\section{Nomenclature}

Oceanographers have traditionally defined dissolved organic carbon (DOC) in seawater as the carbon passing through a filter (e.g. a Whatman GFC fiberglass disc with a nominal pore size of $1.0 \mu \mathrm{m}$ ). This operational definition of DOC is based on size fractionation, rather than the chemical or biochemical characterization of organic carbon, and suffers from a number of limitations. For example, when seawater passes through a filter, organic material is adsorbed onto pore walls (Johnson \& Wangersky 1985, Buffle et al. 1992) and the pore size changes. In addition, the organic material that passes through the filter is difficult to characterize by most of the methods available to analytical chemists. Many of the difficulties encountered in the chemical characterization of DOC are related to the fact that seawater is a complex, salt-rich and poorly-defined solvent (Wangersky 1975, 1993). This means that the definition of DOC by size fractionation is probably here to stay, even though it may have little to do with the composition or reactivity of the so-called dissolved fraction.

Some of the more recent work on DOC has been focused on refinements of size fractionation (e.g. see
Benner et al. 1992, Buffle et al. 1992). In particular, ultrafiltration techniques have been used to subdivide DOC into colloidal organic carbon (COC) and low molecular weight organic carbon (LOC). COC (which is sometimes referred to as submicron or high molecular weight carbon) is made up of organic particles or aggregates between $1 \mathrm{~nm}$ and a few $\mu \mathrm{m}$ in diameter (Stumm 1977, Heimenz 1987). LOC is smaller organic material, with particle diameters of less than $1 \mathrm{~nm}$ (or molecular weights of less than 10000).

\section{Size of organic carbon pools}

DOC in the ocean is recognized as one of the 3 main reservoirs of organic material on the planet, equal to the carbon stored in terrestial plants or soil humus (Hedges 1987). A new analytical technique (Sugimura \& Suzuki 1988) was also thought to recover 200 to $400 \%$ more DOC than older methods (such as photooxidation). This new technique, based on high temperature catalytic oxidation (HTCO) in a vertical furnace, made an organic carbon pool of already global significance assume even more importance. However, since retraction of the original HTCO results by Suzuki (1993), there has been a steady, downward revision of the DOC pool size. HTCO now appears to recover an absolute maximum of 10 to $40 \%$ more DOC than photo-oxidation (Chen \& Wangersky 1993, Ridal \& Moore 1993). Given the recent chequered history of DOC analysis, and the conflicting data that can still be obtained by HTCO (Benner et al. 1992, Martin \& Fitzwater 1992, Ogawa \& Ogura 1992, Tanoue 1992, Sharp 1993), it is important to remember that the size of the marine DOC pool is very much an open question. However, even when these conflicting results are taken into account (Sharp 1993, Sharp et al. 1994), earlier estimates of DOC in the world's ocean (Cauwet 1978; Fig. 1A) are probably not far off values obtained using the present analytical state of the art. DOC still outweighs any other marine source of organic carbon by at least a factor of 10 (Druffel et al. 1992; Fig. 1A).

Measurements of the number of colloid-sized particles in the ocean (Wells \& Goldberg 1992) suggest that COC accounts for 10 to $40 \%$ of total DOC. Results from the ultrafiltration of seawater (Benner et al. 1992, Ogawa \& Ogura 1992, Kepkay et al. 1993) suggest that COC is between 15 and $35 \%$ of the total (Fig. 1B). While these 2 independent techniques are in agreement that the colloidal fraction of DOC is lower than previously suspected (Cauwet 1978), Benner et al. (1992) have also pointed out that COC includes a substantial carbohydrate content, making it a likely candidate for material that can be turned over by biological activity. In addition, even though COC may only be 


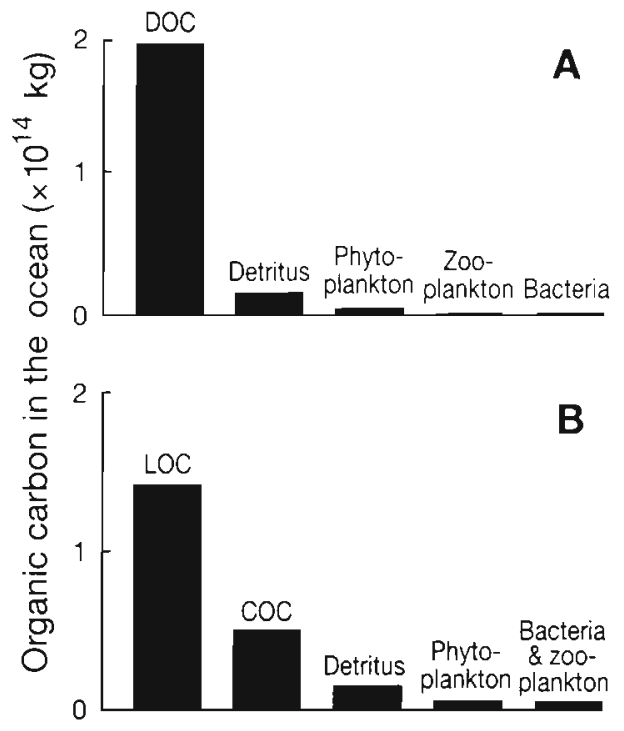

Fig. 1. (A) Dissolved organic carbon (DOC) and other major sources of organic carbon in the world's ocean (adapted from Cauwet 1978). (B) Subdivision of DOC into low molecular weight (LOC) and colloidal (COC) fractions (adapted from Cauwet 1978 using the ultrafiltration results of Benner et al 1992, Ogawa \& Ogura 1992 and Kepkay et al. 1993)

10 to $40 \%$ of total DOC, it still outweighs other marine sources of particulate organic carbon by a wide margin (Fig. 1B). When this is combined with the possibility that COC is bioreactive, any process affecting the degradation of colloids will have far-reaching effects on the cycling of a globally significant carbon pool.

\section{Source of DOC and COC}

While small organic particles can be generated during the physical or biological breakdown of larger aggregates (Hunt 1980, McCave 1984, Wells \& Goldberg 1993b), the ultimate source of marine organic material is phytoplankton production in the photic zone (Druffel et al. 1992). Unfortunately, there is very little information available on the relationship between DOC and the organic exudates released by the phytoplankton. There have been only 2 studies of DOC release by phytoplankton in culture (Sharp 1973, Chen \& Wangersky 1993) and some recent work on the release of translucent extracellular polymers (Alldredge et al. 1993, Passow et al. 1994). There are, however, a number of studies (reviewed by Van Es \& Meyer-Reil 1982, Fogg 1983, 1986) delineating the production of extracellular exudates by ${ }^{14} \mathrm{C}$-labelled phytoplankton and the rapid, biological turnover of these exudates.

The absence of any clear cut evidence for the production of DOC by the phytoplankton may be related to the limited data available on low molecular weight and colloidal fractions. For example, Kepkay et al. (1993) have found that first LOC, and then COC, accumulates in the mixed layer of coastal waters during the decline of a phytoplankton bloom. This accumulation was apparent even though DOC (as the total of the 2 fractions) remained almost invariant. From these data, it is clear that the flux of COC should be included as a specific parameter in models of DOC transport to the deep ocean (Bacastow \& Maier-Reimer 1991). To obtain an accurate estimate of this flux, the bioreactivity of DOC as a whole (and COC in particular) must be accounted for.

\section{Reactivity of DOC and COC}

While the bioreactivity of DOC is obviously an important issue in oceanography (Toggweiler 1990, 1992 , 1993), the quantification of reactivity is no easy task. For example, Kepkay \& Wells (1992) have found a positive linear correlation of DOC with chlorophyll and an inverse correlation of DOC with apparent oxygen utilization (AOU) in the upper $100 \mathrm{~m}$ of coastal and oceanic waters. At first glance, the correlations suggest that the DOC produced by phytoplankton can be broken down and respired to $\mathrm{CO}_{2}$. However, Tanoue (1992) and Kepkay et al. (1993) have pointed out that the correlations cannot be applied ocean-wide and may be more casual than systematic. Other processes, such as photochemical oxidation (Mopper et al. 1991), contribute to the degradation of DOC in the upper ocean, and it has simply not been possible to establish a consistent and reproducible relationship between DOC and AOU or phytoplankton biomass.

The problems encountered when determining the reactivity of DOC are perhaps best illustrated in a long-standing paradox: DOC (on the basis of its ${ }^{14} \mathrm{C}$ content) appears to be quite unreactive over time spans on the order of decades to hundreds of years (Williams \& Druffel 1987, Bauer et al. 1992). Yet it has to be considerably more reactive than the above measurements would suggest, in order to maintain a balance between organic carbon and $\mathrm{CO}_{2}$ inputs to the surface and deep oceans (Hedges 1987).

While this review is devoted primarily to the reactivity of colloid-sized material, it is important to remember that LOC in the ocean outweighs COC by a factor of 2 (Fig. 1B). Unfortunately, almost nothing is known about the reactivity of DOC as a whole, let alone the reactivity of LOC in relation to COC. However, the predominance of the DOC reactivity paradox is graphically illustrated in the data of Sambrotto et al. (1993). They have suggested that anomalously high phytoplankton production is required in both coastal and 
open ocean waters to explain high $\mathrm{CO}_{2}$ influxes from the atmosphere at certain times of year. If this high production does indeed exist, it does not reach the deep ocean and has to be recycled back to $\mathrm{CO}_{2}$ by respiration in surface waters.

The question now becomes: How much phytoplankton production is in the form of COC and how much of the $\mathrm{COC}$ is bioreactive, i.e. broken down and respired to $\mathrm{CO}_{2}$, before it reaches deep water? There are plenty of studies illustrating the rapid breakdown of relatively young ${ }^{14} \mathrm{C}$-labelled exudates that are closely associated with labelled algal cells (reviewed by Van Es \& Meyer-Reil 1982, Fogg 1983, 1986). It is difficult, however, to extrapolate these results to the slower breakdown of older exudates that probably make up the bulk of LOC and COC released 1 to $2 \mathrm{wk}$ after the peak of a bloom (Pett 1989, Kepkay et al. 1993).

\section{AGGREGATES - BIOREACTORS FOR COC}

There is little doubt that the bacteria in aggregates are active. Through their production of exoenzymes (Chrost 1990 with references, Smith et al. 1992, Hoppe et al. 1993), these bacteria are capable of breaking down and mobilizing the larger (colloidal and particulate) components of an aggregate. Smith et al. (1992) have measured such intense hydrolytic enzyme activities that they refer to aggregates as 'enzymatic reactors'. The concept that aggregates act as bioreactors for accumulated $\mathrm{COC}$ is at odds with the fact that $\mathrm{DOC}$ (including $\mathrm{COC}$ ) appears to be remarkably unreactive when it is not aggregated (Hedges 1987, Williams \& Druffel 1987, Bauer et al. 1992). This leads to an important question: How does COC escape degradation by the bacteria?

\section{Restrictions of bacterial access to COC}

The larger size fraction of COC may escape bacterial degradation by virtue of its particle size. Johnson \& Kepkay (1992) found that larger colloids (including bacteria) between about $200 \mathrm{~nm}$ and $2 \mu \mathrm{m}$ in diameter are located at a broad minimum between 2 transport regimes (Fig. 2). Smaller colloids are transported to bacterial cells by Brownian motion and/or convective diffusion, while particles greater than a few $\mu \mathrm{m}$ in diameter are more effectively transported by collision with cells in turbulent shear. This means that the larger colloidal fraction may survive as a resource that is largely untapped by the bacteria.

In order to gain better access to larger colloids, bacteria have to expend energy by swimming to increase the probability of particle interceptions (Johnson \&

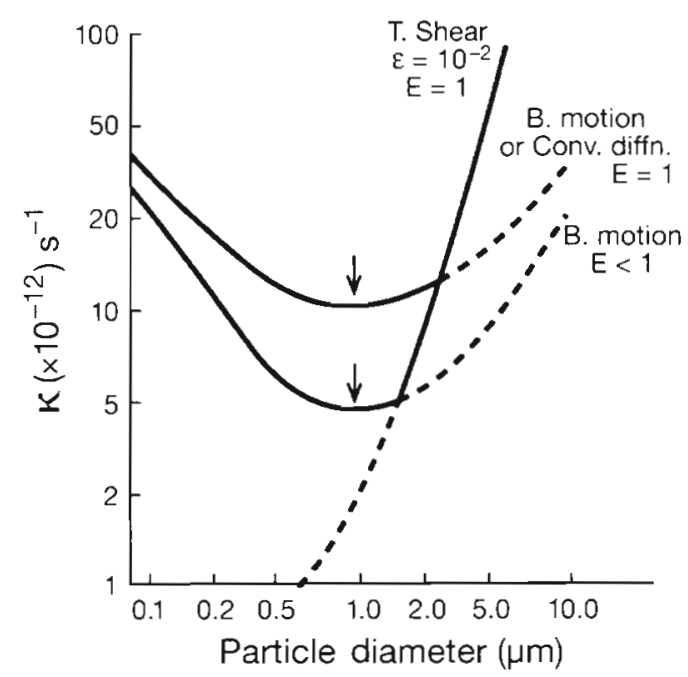

Fig. 2. Curves of rate constants ( $\kappa$ ) for particle transport to a $1 \mu \mathrm{m}$ bacterial cell by Brownian motion, convective diffusion and turbulent shear (Johnson \& Kepkay 1992) using a turbulent energy dissipation rate $(\varepsilon)$ that is typical of rates found near the ocean ocean surface $\left(1 \times 10^{-2} \mathrm{~cm}^{2} \mathrm{~s}^{-3}\right)$. In addition, collision efficiencies $(E)$ of 1 or $<1$ have been used to plot the transport curves (from Johnson \& Kepkay 1992). Broad transport minima (arrowed) are apparent between particle diameters of about $200 \mathrm{~nm}(0.2 \mu \mathrm{m})$ and $2 \mu \mathrm{m}$

Kepkay 1992). They also need to expend energy to produce exoenzymes so that larger colloids can be broken down to low molecular weight substrates and respired internally. Aggregation not only brings larger colloids into the regime dominated by turbulent shear, it also brings them into close contact with bacterial cells (Johnson et al. 1986, Kepkay \& Johnson 1989). As a result, the bacteria need only expend energy on exoenzyme production to gain access to the larger size fraction of $\mathrm{COC}$.

\section{Aggregates, exoenzymes and uncoupled bacterial growth}

Smith et al. (1992) have pointed out that the mobilization of aggregate carbon by exoenzymes allows aggregates to be a source as well as a sink for DOC and COC. The production of low molecular weight organics in these bioreactors exceeds consumption by at least an order of magnitude. The reason why hydrolysis remains uncoupled from the bacterial consumption of its end-products is not clear. However, Smith et al.'s (1992) definition of consumption is based solely on ${ }^{3} \mathrm{H}$-leucine incorporation into the growth of bacterial biomass. There are no estimates of how much of the LOC and COC produced by hydrolysis is consumed by respiration. 
Simultaneous measurements of exoenzyme activity, respiration and the 2 size fractions of DOC are essential for any real understanding of the role of aggregates as bioreactors for organic carbon. These measurements are of particular importance, given the ongoing downward revision of DOC concentrations (Sharp 1993), the discovery of a new class of translucent algal exudates (Alldredge et al. 1993, Passow et al. 1994) and the role played by aggregation in the scavenging of colloid-sized material.

\section{COLLOID AGGREGATION}

\section{Nomenclature}

Aggregation, coagulation and flocculation are terms that have often been used interchangeably by oceanographers to describe the formation of larger from smaller particles. Several authors (e.g. Johnson et al. 1990) have suggested that flocculation is specifically related to the binding of particles by high molecular weight polymers, while coagulation is restricted to particle-binding by charge neutralization through electrical double-layer compression. Others (e.g. Stumm \& Morgan 1981) use the same terms in the opposite sense, so that flocculation is related to double layer compression and coagulation is associated with polymer bridging

In response to this conflict, I will use aggregation in its most general sense to encompass all of the factors contributing to the formation of larger particles (La Mer \& Healy 1963, Tomi \& Bagster 1978). I will also add one more note of caution: theoretical treatments of colloid aggregation in the ocean are based on the assumption that colloids are particles with simple shapes. This is not always the case in seawater, where COC can often take the form of complex, branching structures (Wells \& Goldberg 1993).

\section{Collision efficiency and particle stickiness}

Aggregation is a 2-step process; particles must first collide and then stick together. The physical factors involved in particle collisions have already been wellreviewed (e.g. see McCave 1984, O'Melia 1987. O'Melia \& Tiller 1993 with references). To summarize, the hydrodynamic factors involved in collisions between colloidal particles are accounted for in estimates of the collision efficiency, $E$ (e.g. see Hill 1992 with references, Johnson \& Kepkay 1992). The probability that particles will stick together after collision has been defined as the coalescence efficiency (McCave 1984) or coagulation efficiency (Jackson 1990, Kiørboe et al. 1990, Jackson \& Lochman 1993).
Particle stickiness will be affected by all of the hydrodynamic factors included in $E$, but coagulation efficiency is more difficult to determine because it includes a number of physical and biological factors that cannot be precisely defined (Johnson et al. 1990) Nearly all of the most recent estimates of particle stickiness (Kiørboe et al. 1990, Riebesell 1991a, b, Hill 1992, Jackson \& Lochman 1993, Kiørboe \& Hansen 1993) are concerned specifically with phytoplankton cells in culture or natural waters.

The stickiness of bacterial cells has been expressed in terms of short-range hydrodynamic and van der Waal's forces (Van Loosdrecht et al. 1989), but very little is known about the stickiness of other colloid-sized particles. For instance, McCave (1984) has used a coagulation efficiency of 0.1 to model colloid aggregation. In contrast, Wells \& Goldberg (1992) have found that the coagulation efficiency of 5 to $100 \mathrm{~nm}$ colloids is an absolute maximum of 0.001 . This far lower value for the coagulation efficiency of small colloids is in agreement with O'Melia \& Tiller's (1993) and O'Melia \& Yang's (1994) concept of electrosteric stabilization. Electrostatic repulsion between small particles is screened at the high ionic strengths of seawater, allowing macromolecules adsorbed onto the particle surfaces to assume relatively thick conformations (O'Melia \& Tiller 1993). In turn, the adsorbed macromolecules allow kinetically stable suspensions of the small particles to develop (O'Melia \& Yang 1994), but the resistance of these suspensions to the effects of aggregation has yet to be quantified

On a larger scale, phytoplankton cells and aggregates are almost always preconditioned by a film of bacteria and colloidal material in natural waters (Marshall et al. 1971, Egan 1987, Vaque et al. 1990). More information is needed on the coagulation efficiency of cells and aggregates in the presence and absence of this conditioning film

\section{Collision mechanisms}

Within the colloidal (submicron) region of the size spectrum, a number of mechanisms contribute to the collision of suspended particles (Fig. 3):

1. Brownian motion. Particles smaller than a few $\mu \mathrm{m}$ in diameter undergo random walk due to the impact of solute molecules (Fig. 3A). This multi-directional transport of particles on a small scale is a major factor contributing to particle collisions in the colloid size range (McCave 1984, Farley \& Morel 1986, O'Melia 1987. Johnson \& Kepkay 1992, O'Melia \& Tiller 1993).

2. Shear. Particles following steamlines and/or eddies that are closer together than the distance between their centers will collide in laminar or turbu- 


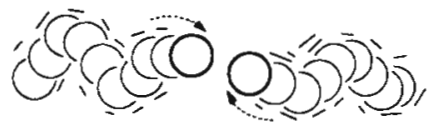

A. Brownian Motion

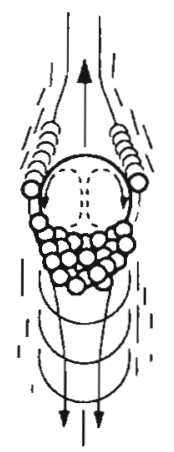

E. Surface Coagulation

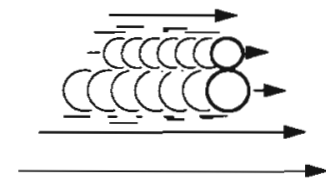

B. Shear

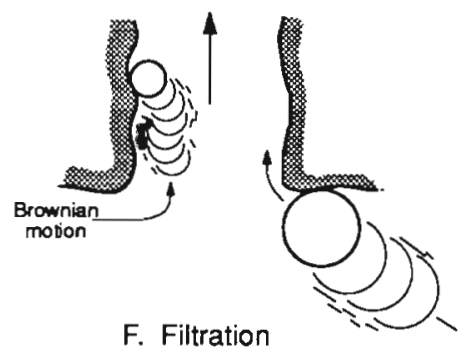

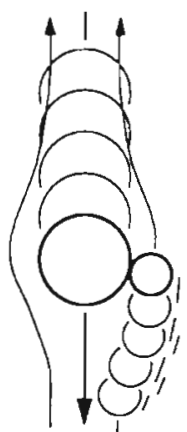

C. Differential Sedimentation

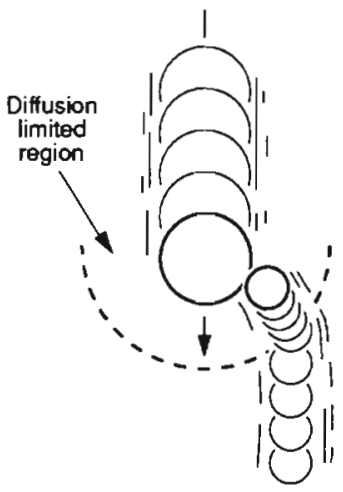

D. Diffusive Capture

Fig. 3. Collision mechanisms that contribute to the aggregation of colloid-sized particles (adapted from Johnson et al. 1990). Collision mechanisms include (A) Brownian motion, (B) turbulent or laminar shear, (C) differential settling, (D) diffusive capture, (E) surface coagulation, (F) filtration and (G) bacterial motility

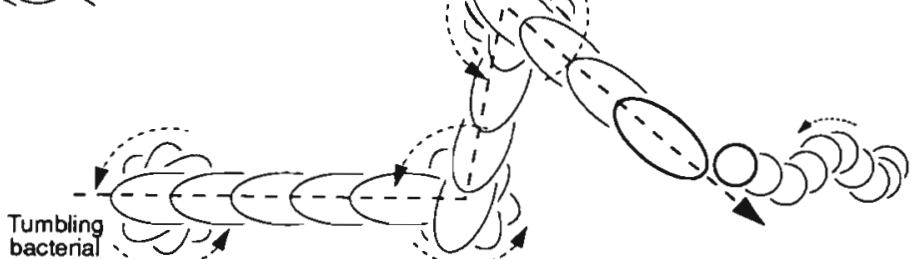

G. Bacterial Motility lent shear (Fig. 3B). This process of collision in shear is typically important for particles larger than a few $\mu \mathrm{m}$ in diameter (McCave 1984, O'Melia 1987, Hill et al. 1992, Johnson \& Kepkay 1992, O'Melia \& Tiller 1993) and less important than Brownian motion for particles in the submicron size range.

3. Differential settling. Rapidly settling particles can overtake and intercept smaller particles (Fig. 3C). As in the case of fluid shear, collision will depend on the particles following streamlines that are closer together than the distance between their centers (Melik \& Fogler 1984). This process is probably more important in the ocean interior and less important than shearbased collisions in the greater turbulence encountered near the ocean surface (McCave 1984).

4. Diffusive capture. A diffusion-limited boundary layer is established around the surface of a settling particle (Fig. 3D). Outside this layer, advection is the predominant mechanism of particle transport. Within the layer, diffusion becomes important. The effective thickness of the boundary layer is a function of particle size, settling speed and diffusivity. In the case of colloids, diffusive capture is one of the more important aspects of differential sedimentation in the ocean interior (McCave 1984, Johnson \& Kepkay 1992).

5. Surface coagulation. The aggregation of colloids at the air-sea interface, especially on rising bubbles, is known as surface coagulation (Johnson et al. 1986). A bubble injected into the water initially rises with a mobile interface between the gas and liquid phase. The mobility of the interface is maintained by gas circulation within the bubble (Fig. 3E) and the tangential velocity at the bubble surface is not zero (as it is at the surface of a solid sphere). Streamlines are drawn towards the surface (Fig. 3E) and colloid-sized particles are transported to the bubble with an efficiency that is orders of magnitude greater than the transport of particles to a solid sphere (Johnson et al. 1990). This means that surface coagulation is one of the most important mechanisms of colloid aggregation in the upper ocean even though its effects are restricted to the mixed layer (Kepkay \& Johnson 1989). The convective diffusion of particles to a mobile interface bubble is also enhanced relative to a solid sphere but, as the bubble continues to rise and age, material accumulates on the surface and is swept to the rear (Fig. 3E). Further accumulations cause the bubble to become rigid, as an immobile interface is established, with all the particle interception and collision characteristics of a solid sphere.

6. Filtration. Macroaggregates (marine snow) have pores that allow significant water flow during particle settling (Logan \& Hunt 1987). Larger colloids can be collected by these pores through size exclusion, while particles smaller than the pore size can collide with the pore wall through convective diffusion or interception (Fig. 3F). While this combination of processes has been modelled in terms of filtration through a cylindrical 
pore (Johnson \& Wangersky 1985) and the scavenging of small particles by a rapidly-sinking porous sphere (Stolzenbach 1993), its contribution to colloid scavenging by natural macroaggregates remains to be determined.

7. Bacterial motility. One of the primary biological contributers to collisions between colloids is bacterial cell motility (Johnson \& Kepkay 1992), but aggregates can also be generated by the activities of larger organisms, such as suspension feeders (Shimeta 1993). The aggregates produced by feeding can be the organism itself (Tranvik et al. 1993) or particle-loaded mucous webs, such as those manufactured by planktonic tunicates (Flood et al. 1992). Bacterial motility has commonly been treated as a diffusive process (Lauffenberger 1983), but a consideration of scales indicates that this approach is not valid for the interaction of bacteria with colloid-sized particles (Fig. 3G). Nutrientlimited bacteria have been observed to swim at velocities of up to $30 \mu \mathrm{m} \mathrm{s}^{-1}$ for run times of about $1 \mathrm{~s}$ and then tumble (Fig. 3G) before initiating a new run (Lauffenberger 1983). This means that bacteria can travel many times the dimensions of even the largest colloids during a single run (Johnson \& Kepkay 1992), and cause particle collisions by interception rather than diffusion. At this point, however, it is not possible to assess (in any general sense) the contribution of bacterial motility to colloid aggregation.

\section{Colloid aggregation and the Brownian pump}

While a number of excellent theoretical treatments of particle collision and adhesion have recently appeared in the literature (e.g. see O'Melia 1987, O'Melia \& Tiller 1993 with references), McCave (1984) has produced the summary most relevant to the open ocean. Modifying the approach taken by Friedlander (1965) and Hunt (1980), McCave delineated specific regions of the particle size spectrum associated with specific collision mechanisms. Brownian motion is predominant where particles (including bacteria) are less than a few $\mu \mathrm{m}$ across; differential sedimentation and turbulent shear are most significant in the transport of larger particles.

The association of a specific collision mechanism with a specific particle size range is in agreement with Friedlander's (1960a, b, 1965) contention that there is a flux of particles from smaller to larger sizes in an equilibrium or 'quasi-stationary' size spectrum. On a submicron scale, the flux (referred to as the Brownian pump) is driven by collisions between particles of similar size (Jeffrey 1981, McCave 1984) to produce small aggregates. The small aggregates collide to make bigger aggregates and so on up to particulate sizes (greater than a few $\mu \mathrm{m}$ across).
When compared to residence times in the open ocean, the time constant for aggregation by the Brownian pump can be long. McCave (1984) calculated that 3 mo to 20 yr would be required for Brownian aggregation to reduce the number of $500 \mathrm{~nm}$ particles by half when coagulation efficiency is 0.1 and particle concentrations are $4 \times 10^{5} \mathrm{ml}^{-1}$ (in deep-ocean nepheloid layers) or $4 \times 10^{3} \mathrm{ml}^{-1}$ (in mid-water). The results from work using thorium isotopes as in situ tracers (Clegg \& Whitfield 1991, Santschi \& Honeyman 1991a, b, Baskaran et al. 1992, Moran \& Buessler 1992, 1993) suggest the opposite - that rapid particle aggregation and the possible degradation of aggregates by respiration are responsible for the short residence time of colloids in the upper ocean.

The conflict can be partially resolved by considering recent measurements of the number of submicron particles in seawater. Koike et al. (1990) and Wells \& Goldberg $(1991,1992,1993)$ have suggested that the concentration of colloid-sized material can be as high as $10^{7}$ to $10^{9} \mathrm{ml}^{-1}$. This continuum of small particles and aggregates between 5 and $200 \mathrm{~nm}$ in diameter (Wells \& Goldberg 1994) is $10^{2}$ to $10^{6}$ times more abundant than the particle concentrations used by McCave to estimate Brownian aggregation times. Given the dependance of aggregation rate on the square of particle concentration in the Brownian collision equation (Smolouchowski 1917), higher particle concentrations should speed up the Brownian pump substantially. However, the electrosteric stabilization of smaller colloids by adsorbed macromolecules (O'Melia \& Tiller 1993, O'Melia \& Yang 1994) will tend to work in opposition. As a result, there is still no clear picture of the quantitative contribution made by the Brownian pump to the aggregation of colloids.

Even if Brownian aggregation is not faster than previously suspected, there are 3 other processes - colloid scavenging by turbulent shear, scavenging by filtration through rapidly settling porous aggregates and scavenging by surface coagulation - that can accelerate the aggregation of colloids.

\section{Scavenging of colloids by larger particles and aggregates}

The results from McCave's (1984) models demonstrate that collisions between colloid-sized and larger particles are accelerated by turbulent shear. Hill et al. (1992) also found that that the effects of turbulent shear can extend down to the Kolmogorov scale and below. This means that the scavenging of colloids by larger aggregates is most important in regions of higher turbulence, such as those found near the ocean surface. In addition, Stolzenbach (1993) found that col- 
loids can be efficiently scavenged by filtration through rapidly sinking, porous aggregates. It is clear, then, that colloid scavenging by larger particles or aggregates (McCave 1984, O'Melia 1987, Confer \& Logan 1991, Santschi \& Honeyman 1991a, b, Buffle et al. 1992, Honeyman \& Santschi 1992, Stolzenbach 1993) cannot be ignored, especially during the mass aggregation of organic material at the end of phytoplankton blooms (Alldredge \& Gottschalk 1988, Kranck \& Milligan 1988, Jackson 1990, Riebesell 1991a, b, Hill 1992, Jackson \& Lochman 1993, Kepkay et al. 1993).

Another mechanism for the rapid aggregation of colloids - surface coagulation - should also be taken into account, especially given the predominance of this process (Johnson et al. 1986, 1990) in the production of aggregates in the upper ocean.

\section{Colloids, bacteria and surface coagulation}

The concept that aggregates of organic material and bacteria (Fig. 4) are generated by the coagulation of larger $(0.2$ to $1 \mu \mathrm{m})$ colloids on bubble surfaces has been advanced at regular intervals during the last 30 yr (Blanchard 1983, Johnson et al. 1986, Kepkay \& Johnson 1989 with references). Until recently, the large number of conflicting reports in the literature has made it difficult to assess the contribution of surface coagulation to particle dynamics in the upper ocean.

Johnson et al. (1986) and Kepkay \& Johnson (1989) reconciled these conflicts by combining theory and experiment to delineate the role of surface coagulation in systems representing the real ocean. They found that filtering seawater through anything finer than a $2 \mu \mathrm{m}$ pore size removes the larger $\mathrm{COC}$ available for coagulation onto bubble surfaces. In addition, rising bubbles of about $500 \mu \mathrm{m}$ in diameter are the most efficient scavengers of COC. With proper control of filtration, bubble size and rise distance, bacteria are not required for aggregate formation, but they do multiply rapidly to become an important component of the aggregates within hours of their formation (Fig 4). For the first time, a well-defined link had been established between the aggregation of a specific size fraction of COC (in this case by surface coagulation) and bacterial growth.

\section{AGGREGATES, BACTERIA AND RESPIRATION}

Kepkay \& Johnson (1989) found that once COC is brought into close contact with bacteria by surface coagulation, respiration can increase by as much as 36 times (Fig. 5), but only for 2 to $4 \mathrm{~h}$. The bacteria responsible for this increase in respiration (Kepkay \& Johnson

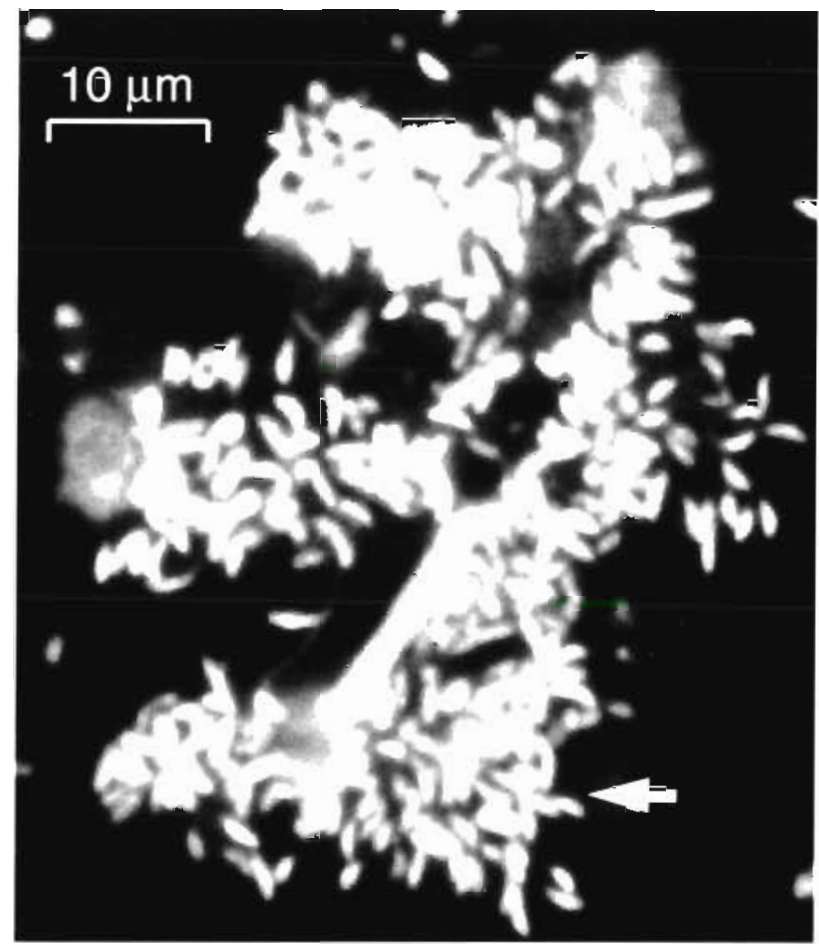

Fig. 4. Epifluorescence photo-micrograph of an aggregate produced by surface coagulation in a bubbling column and stained by acridine orange to fluoresce under UV light. After the aggregate was formed, bacteria (cell arrowed) grew up in only a few hours

1988) are capable of utilizing COC, but the carbon must first be concentrated with the bacteria into aggregates that are tens of $\mu \mathrm{m}$ to $\mathrm{mm}$ across (Kepkay et al. 1990bi Fig. 4). These were the first results establishing a direct link between colloid aggregation and the bioreactivity (respiration) of COC. The enhancement of respiration by surface coagulation and other forms of aggregation may also have been apparent in earlier data sets, but there are suprisingly few direct measurements of respiration in the literature (Williams 1984).

When the limited data available from the Sargasso Sea are summarized (Fig. 5), there are wide variations in respiration rate. The data of Riley (1939) and Williams \& Jenkinson (1982) suggest that coagulation is not required to obtain high respirations. However, their measurements were taken at a number of stations at different times of year, and are characterized by large, apparently-random variations. In Kepkay et al.'s (1990a) data, the variations in respiration at one station are more systematic; high respirations are associated with surface coagulation in a bubbling column and low respirations are typical of untreated controls.

The random variations of earlier authors could in fact, be systematic, with low respirations associated with quiet seas and higher respirations associated with 


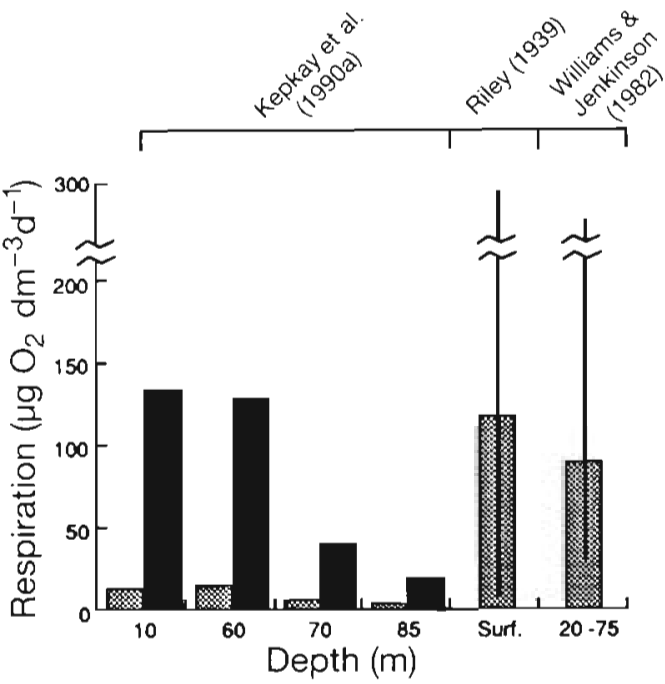

Fig. 5. Respiration measurements reported from a range of depths in the Sargasso Sea over a 51 yr period. In Kepkay et al.'s data (1990a), there is a systematic variation in respiration between seawater that has undergone surface coagulation in a bubbling column (black bars) and untreated controls (shaded bars). Earlier measurements by Riley (1939) and Williams \& Jenkinson (1982) exhibit large, random variations error bars delineate the range around calculated means

surface coagulation produced by episodes of intense bubbling under high seas. Support for this conclusion is apparent in Kepkay's (1991) measurements taken after a storm in the North Atlantic. High respirations could not be induced in seawater collected just after the storm because the COC available for surface coagulation had already been removed by natural bubbling. Instead, respiration in water from a bubbling column was almost identical to respiration in an untreated control. The only water samples where surface coagulation could produce an appreciable enhancement of respiration were taken from water masses that were largely unaffected by the storm.

While there is no doubt that respiration can be enhanced by surface coagulation, different results are obtained when different methods are used. For example, the enhancement of respiration measured as a bulk property by pulsed oxygen electrode in a relatively large $(300 \mathrm{ml})$ water sample is less than the enhancement measured using an oxygen microgradient system applied to aggregates collected on a filter (Kepkay unpubl.). Even then, both types of result will be different from those obtained using the standard technique of measuring oxygen consumption over $24 \mathrm{~h}$ in a BOD bottle.

As Kepkay et al. (1989) have pointed out, the enhancement of respiration by surface coagulation is episodic. It lasts for only a few hours and would not be detected using the relatively coarse sample intervals that are normally employed during $24 \mathrm{~h}$ incubations.
Future measurements of respiration in surface waters should be taken with particular attention paid to the time scale of data acquisition. Only in this way will episodic events (such as those triggered by aggregation) be integrated into the results obtained over longer times.

To arrive at any meaningful predictions of net production by the phytoplankton, it is obviously important to know the rate at which the organic carbon produced by photosynthesis is broken down and respired to $\mathrm{CO}_{2}$ Given the paucity of data on respiration in the ocean, there is clearly a lot of work to do, not only with respect to the measurement of respiration, but also with respect to the inclusion of respiration (and COC reactivity) in models of aggregation (Jackson 1990, Hill 1992, Jackson \& Lochman 1993) and carbon transport to deep water (Hill 1992). In addition, to make any sense of a respiration measurement, the episodic response of respiration to aggregation has to be accounted for explicitly.

\section{BIOREACTIVITY OF COC: A SUMMARY}

Oceanographers have generally treated organic carbon, colloid aggregation and respiration as separate fields of research. When an integrated view is taken of all 3 fields as a whole, new insights are possible:

1. COC is a carbon reservoir of global significance, outweighing the phytoplankton or bacteria by a considerable margin (Fig. 1).

2. Brownian pumping, turbulent shear, differential settling and surface coagulation (Fig. 3) move colloids up the size spectrum and into the detrital carbon pool (Fig. 1A), producing aggregates that are tens of $\mu \mathrm{m}$ to mm across (Fig. 4).

3. Without aggregation, an appreciable fraction of COC in the 0.2 to $1 \mu \mathrm{m}$ size range appears to be less bioreactive because it cannot be easily-accessed by the bacteria (Fig. 2). Only when caught up into aggregates with the bacteria (which are colloid-sized particles in their own right) does the $\mathrm{COC}$ become more reactive. fuelling significant increases in bacterial growth (Fig. 4) and respiration (Fig. 5). It is not clear what degree of preconcentration of both COC and bacteria is required to induce this burst of bacterial activity.

4. Respiration measurements are missing from most oceanographic data sets. The absence of these measurements is particularly important given the apparently uncoupled relationship of exoenzyme production and bacterial growth in aggregates.

5. Respiration and the reactivity of COC must now be included, not only in models of aggregation (Jackson 1990. Hill 1992, Jackson \& Lochman 1993) and the production of a detrital carbon pool, but also in models of 
ocean productivity and the transport of carbon to the ocean interior (Bacastow \& Maier-Reimer 1991, Hill 1992).

Acknowledgements. This review is written in memory of $\mathrm{Dr}$ Kate Kranck (1937-1993). Much of the work outlined in the review is a component of the Canadian Joint Global Ocean Flux Study within the science branch of the Department of Fisheries and Oceans. I am grateful to $T$ Platt for his leadership during the development of Canadian JGOFS. I am also grateful to G. A. Jackson, I. N. McCave, S. E. H. Niven, M. Sinclair, J. R. Toggweiler and M. L. Wells for their encouragement, direction and criticism during my wanderings through the marine colloid literature.

\section{LITERATURE CITED}

Alldredge, A. L., Gottschalk, C. C., MacIntyre, S. (1987). Evidence for sustained residence of macrocrustacean fecal pellets in surface waters of Southern California. Deep Sea Res. 34: 164.1-1659

Alldredge, A. L., Gottschalk, C. C. (1988). Direct observations of mass flocculation of diatom blooms: characteristics, settling velocities and formation of diatom aggregates. Deep Sea Res. 36: 159-171

Alldredge, A. L., Hartwig, E. O. (1986). Aggregate dynamics in the sea: workshop report. American Institute of Biological Science, New York

Alldredge, A. L., Passow, U., Logan, B. E. (1993). The abundance and significance of a class of large transparent organic particles in the ocean. Deep Sea Res. 40: $1131-1140$

Bacastow, R., Maier-Reimer, E. (1991). Dissolved organic carbon in modelling oceanic new production. Global Biogeochem. Cycles 5: 71-85

Banse, K. (1990). New views on the degradation and disposition of organic particles as collected by sediment traps in the open sea. Deep Sea Res. 37: 1177-1195

Baskaran, M., Santschi, P. H., Benoit, G., Honeyman, B. D. (1992). Scavenging of thorium isotopes by colloids in seawater of the Gulf of Mexico. Geochim. Cosmochim. Acta 56: $3375-3388$

Bauer, J. E., Williams, P. M., Druffel, E. R. M. $(1992) .{ }^{14} \mathrm{C}$ activity of dissolved organic carbon fractions in the northcentral Pacific and Sargasso Sea. Nature 357: 667-670

Benner, R., Pakulski, J. D., McCarthy, M., Hedges, J. I., Hatcher, P. G. (1992). Bulk characteristics of dissolved organic matter in the ocean. Science 255: 1561-1564

Blanchard, D. C. (1983). The production, distribution and bacterial enrichment of the sea-salt aerosol. In: Liss, P. S., Slinn, W. G. N. (eds.) Air-sea exchange of gases and particles. Reidel, Boston, p. 407-454

Buffle, J., Perret, D., Newman, M. (1992). The use of filtration and ultrafiltration for size fractionation of aquatic particles colloids and macromolecules. In: Buffle, J., van Leeuwen, H. P. (eds.) Environmental particles, Vol. 1. International Union of Pure and Applied Chemistry, Environmental Analytical and Physical Chemistry Series. Lewis Publishers, Ann Arbor, p. 171-230

Cauwet, G. (1978). Organic chemistry of sea water particulates: concepts and developments. Oceanol. Acta 1. 99-105

Chen, W., Wangersky, P. J. (1993). A high-temperature catalytic oxidation method for the determination of marine dissolved organic carbon and its comparison with the UV photo-oxidation method. Mar. Chem. 42: 95-106

Chrost, R. J. (1990). Microbial exoenzymes in aquatic environments. In: Overbeck, J., Chrost, R. J. (eds.) Aquatic microbial ecology, biochemical and molecular approaches. Springer-Verlag, New York, p. 47-78

Clegg, S. L., Whitfield, M. (1991). A generalized model for the scavenging of trace metals in the open ocean - II. Thorium scavenging. Deep Sea Res. 38: 91-120

Confer, D. R., Logan, B. E. (1991). Increased bacterial uptake of macromolecular substrates with fluid shear. Appl. environ. Microbiol. 57: 3093-3100

Druffel, E. R. M., Williams, P. M., Bauer, J. E., Ertel, J. R. (1992). Cycling of dissolved and particulate organic matter in the open ocean. J. geophys. Res. 97: 15639-15659

Egan, B. (1987). Marine microbial adhesion and its consequences. In: Sleigh, M. A. (ed.) Microbes in the sea. Ellis Horwood, Chichester, p. 220-238

Farley, K. J., Morel, F. M. M. (1986). Role of coagulation in the kinetics of sedimentation. Environ. Sci. Technol. 20: $187-195$

Flood, P. R., Deibel, D., Morris, C. C. (1992). Filtration of colloidal melanin from seawater by planktonic tunicates. Nature 355: 630-632

Fogg, G. E. (1983). The ecological significance of extracellular products of phytoplankton photosynthesis. Botanica mar. 26: $3-14$

Fogg, G. E. (1986). Picoplankton. Proc. R. Soc. Lond. B 228 : $1-30$

Friedlander, S. K. (1960a). On the particle-size spectrum of atmospheric aerosols. J. Meteorol. 17: 373-374

Friedlander, S. K. (1960b). Similarity considerations for the particle-size spectrum of a coagulating, sedimenting aerosol. J. Meteorol 17: 479-483

Friedlander, S. K. (1965). The similarity theory of the particlesize distribution of the atmospheric aerosol. In: Spurny, K. (ed.) Aerosols, physical chemistry and applications. Czechoslovakian Academy of Science, Prague, p. 115-130

Hedges, J. I. (1987). Organic matter in sea water. Nature 330 205-206

Heimenz, P. C. (1987). Principles of colloid and surface chemistry. Marcel Dekker, New York

Hill, P. S. (1992), Reconciling aggregation theory with observed vertical fluxes following phytoplankton blooms. J. geophys. Res. 97: 2295-2308

Hill, P. S., Nowell, A. R. M., Jumars, P. A. (1992) Encounter rate by turbulent shear of particles similar in diameter to the Kolmogorov scale. J. mar. Res. 50: 643-668

Honeyman, B. D., Santschi, P. H. (1989). A Brownianpumping model for oceanic trace metal scavenging: evidence from Th isotopes. J. mar. Res. 47: 951-992

Honeyman, B. D., Santschi, P. M. (1992). The role of particles and colloids in the transport of radionuclides and trace metals in the oceans. In: Buffle, J., van Leeuwen, H. P. (eds.) Environmental particles, Vol. 1. International Union of Pure and Applied Chemistry, Environmental Analytical and Physical Chemistry Series. Lewis Publishers, Ann Arbor, p. 379-423

Honjo, S (1980). Material fluxes and modes of sedimentation in the mesopelagic and bathypelagic zones. J. mar. Res. 38: $53-97$

Hoppe, H.-G., Ducklow, H., Karrasch, B. (1993). Evidence for dependancy of bacterial growth on enzymatic hydrolysis of particulate organic matter in the mesopelagic ocean. Mar. Ecol. Prog. Ser. 93: 277-283

Hunt, J. R. (1980). Prediction of oceanic particle-size distributions from coagulation and sedimentation mechanisms. In: Kavanaugh, M. C., Leckie, J O. (eds.) Particulates in 
water. Am. Chem. Soc., Advances in Chemistry series No. 189, Washington, DC, p. 243-257

Jackson, G. A. (1990). A model of the formation of marine algal flocs by physical coagulation processes. Deep Sea Res. 37: 1197-1211

Jackson, G. A., Lochman, S. (1993). Modelling coagulation of algae in marine ecosystems. In: Buffle, J., van Leeuwen, H. P. (eds.) Environmental particles, Vol. 2. International Union of Pure and Applied Chemistry, Environmental Analytical and Physical Chemistry Series. Lewis Publishers, Ann Arbor, p. 387-413

Jeffrey, D. J. (1981). Quasi-stationary approximations for the size distribution of aerosols. J. Atmos. Sci. 38: 2440-2443

Johnson, B. D., Kepkay, P. E. (1992). Colloid transport and bacterial utilization of oceanic DOC. Deep Sea Res. 39: $855-869$

Johnson, B, D., Kranck, K., Muschenheim, D. K. (1990). Physico-chemical factors in particle aggregation. In: Wotton, R. (ed.) The biology of particles in aquatic systems. CRC Press, Boca Raton, p. 57-81

Johnson, B. D., Wangersky, P. J. (1985). Seawater filtration: particle flow and impaction considerations. Limnol. Oceanogr. 30: 966-971

Johnson, B. D., Zhou, X. L., Wangersky, P. J. (1986). Surface coagulation in seawater. Neth. J. Sea Res. 20: 201-210

Kepkay, P. E. (1991). Surface coagulation and microbial respiration in response to local advection and sea state in the North Atlantic. Mar. Ecol. Prog. Ser. 69: 143-147

Kepkay, P. E., Harrison, W. G., Irwin, B. (1990a). Surface coagulation, microbial respiration and primary production in the Sargasso Sea. Deep Sea Res. 37: 145-155

Kepkay, P. E., Johnson, B. D. (1988). Microbial response to organic particle generation by surface coagulation in seawater. Mar. Ecol. Prog. Ser. 48: 193-198

Kepkay, P. E., Johnson, B. D. (1989). Coagulation on bubbles allows the microbial respiration of oceanic dissolved organic carbon. Nature 385: 63-65

Kepkay, P. E., Muschenheim, D. K., Johnson, B. D. (1990b). Surface coagulation and microbial respiration at a tidal front on Georges Bank. Cont. Shelf. Res. 10:573-588

Kepkay, P. E., Niven, S. E. H., Milligan, T. G. (1993). Low molecular weight and colloidal DOC production during a phytoplankton bloom. Mar. Ecol. Prog. Ser. 100: 233-244

Kepkay, P. E., Wells, M. L. (1992). Dissolved organic carbon in North Atlantic surface waters. Deep Sea Res. 80: 275-283

Kiørboe, T., Andersen, K. P., Dam, H. G. (1990). Coagulation efficiency and aggregate formation in marine phytoplankton. Mar. Biol. 107: 235-245.

Kiørboe, T., Hansen, J. L. S. (1993). Phytoplankton aggregate formation: observations of patterns and mechanisms of cell sticking and the significance of exopolymeric material. J. Plankton Res. 15: 993-1018

Koike, I., Shigemitsu, H., Terauchi, K., Kogure, K. (1990). Role of sub-micrometre particles in the ocean. Nature 345 : $242-244$.

Kranck, K., Milligan, T. G. (1988). Macroflocs from diatoms: in situ photography of particles in Bedford Basin. Mar. Ecol. Prog. Ser. 44: 183-189

La Mer, V. K., Healy, T. W. (1963). The role of filtration in investigating flocculation and redispersion of colloidal dispersions. J. phys. Chem. 67: 2417

Lauffenberger, D. A. (1983). Effects of cell motility properties on cell populations in ecosystems. In: Blanch, $\mathrm{H}$. W., Papoutsakis, E. T., Stephanopoulos, G. (eds.) Foundations of biochemical engineering: kinetics and thermodynamics in biological systems. Am. Chem. Soc., Washington, DC, p. $266-292$
Logan, B. E., Hunt, J. R. (1987). Advantages to microbes of growth in permeable aggregates in marine systems. Limnol. Oceanogr. 32: 1034-1048

Marshall, K. C., Stout, R., Mitchell, R. (1971). Mechanism of the initial events in the sorption of marine bacteria to surfaces. J. gen. Microbiol. 66: 337-348.

Martin, J. H., Fitzwater, S. E. (1992). Dissolved organic carbon in the Atlantic, Southern and Pacific oceans. Nature 356 $699-700$

McCave, I. N. (1984). Size spectra and aggregation of suspended particles in the deep ocean. Deep Sea Res. 32: $329-352$

Melik, D. H., Fogler, H. S. (1984). Gravity-induced flocculation. J. Coll. Int. Sci. 101: 72-83

Mopper, K., Zhou, X. L., Kieber, R. J., Kieber, D. J., Sikorski, R. J., Jones, R. D. (1991). Photochemical degradation of dissolved organic carbon and its impact on the oceanic carbon cycle. Nature 353: 60-62

Moran, S. B., Buessler, K. O. (1992). Short residence time of colloids in the upper ocean estimated from ${ }^{238} \mathrm{U}-{ }^{234} \mathrm{Th}$ disequilibria. Nature 359: 221-223

Moran, S. B., Buessler, K. O. (1993). Size-fractionated ${ }^{234} \mathrm{Th}$ in continental shelf waters off New England: implications for the role of colloids in oceanic trace metal scavenging J. mar. Res. 51: 893-922

Ogawa, H., Ogura, N. (1992). Comparison of two methods for measuring dissolved organic carbon in sea water. Nature 356: $696-698$

O'Melia, C. R. (1987). Particle-particle interactions. In Stumm, W. (ed.) Aquatic surface chemistry. John Wiley \& Sons, New York, p. 385-404

O'Melia, C. R., Tiller, C. L. (1993). Physicochemical aggregation and deposition in aquatic environments. In: Buffle, J., van Leeuwen, H. P. (eds.) Environmental particles, Vol. 2 International Union of Pure and Applied Chemistry, Environmental Analytical and Physical Chemistry Series Lewis Publishers, Ann Arbor, p. 353-385

O'Melia, C. R., Yang, S. (1994). Chemical and physical aspects of aggregation in marine environments. Abstr. Nat. Meeting Am. Chem. Soc. Part 1: 170

Passow, U., Alldredge, A. L., Logan, B. E. (1994). The role of particulate carbohydrate exudates in the flocculation of diatom blooms. Deep Sea Res. 41: 335-357

Pett, R. J. (1989). Kinetics of microbial mineralization of organic carbon from detrital Skeletonema costatum cells. Mar. Ecol. Prog. Ser. 52: 123-128

Ridal, J. J., Moore, R. M. (1993). Resistance to UV and persulfate oxidation of dissolved organic carbon produced by selected marine phytoplankton. Mar. Chem. 42: 167-188

Riebesell, U. (1989). Comparison of sinking and sedimentation rate measurements in a diatom winter/spring bloom Mar. Ecol. Prog. Ser. 54: 109-119

Riebesell, U. (1991a). Particle aggregation during a diatom bloom. I. Physical aspects. Mar. Ecol. Prog. Ser. 69: $273-280$

Riebesell, U. (1991b). Particle aggregation during a diatom bloom. II. Biological aspects. Mar. Ecol. Prog. Ser. 69 $281-290$

Riley, G. A. (1939). Plankton studies III. The Western North Atlantic, May-June 1939. J. mar. Res. 2: 145-162

Sambrotto, R. N., Savidge, G., Robinson, C., Boyd, P., Takahashi, T., Karl, D. M., Langdon, C., Chipman, D., Marra, J., Codispoti, L. (1993). Elevated consumption of carbon relative to nitrogen in the surface ocean. Nature $363: 248-250$

Santschi, P. H., Honeyman, B. D. (1991a). Radioisotopes as tracers for interactions between trace elements, colloids and particles in natural waters. In: Vernet, J.-P. (ed.) Trace 
metals in the environment 1 . Heavy metals in the environment. Elsevier, New York, p. 229-246

Santschi, P. H., Honeyman, B. D. (1991b). Are thorium scavenging and particle fluxes in the ocean regulated by coagulation? In: Kershaw, P. J., Woodhead, D. S. (eds.) Radionuclides in the study of marine processes. Elsevier Applied Science, New York, p. 107-115

Sharp, J. H. (1973). Total organic carbon in seawater comparison of measurements using persulfate oxidation and high temperature combustion. Mar. Chem. 1: $211-229$

Sharp, J. H. (1993). The dissolved organic carbon controversy: an update. Oceanography 6: 45-50

Sharp, J. N., Bennet, R., Carlson, C. A., Dow, R., Fitzwater, S. E. (1994). Re-evaluation of high temperature combustion and chemical oxidation for measurements of dissolved organic carbon in seawater. Limnol. Oceanogr. 38: $1774-1782$

Shimeta, J. (1993). Diffusional encounter of submicrometer particles and small cells by suspension feeders. Limnnol. Oceanogr. 38: 456-465

Smith, D. C., Simon, M., Alldredge, A. L., Azam, F. (1992). Intense hydrolytic enzyme activity on marine aggregates and implications for rapid particle dissolution. Nature 359: $139-142$

Smolouchowski, M. von (1917). Versuch einer mathematischen Theorie der Koagulationskinetik Kolloider Lösungen. Z. phys. Chem. (Leipzig) 92: 129-168

Stolzenbach, K. D. (1993). Scavenging of small particles by fast-sinking porous aggregates. Deep Sea Res. 40: $359-369$

Stumm, W. (1977). Chemical interactions in particle separation. Env. Sci. Technol. 11: 1066-1070

Stumm, W., Morgan, J. J. (1981). Aquatic chemistry. WileyInterscience, New York

Sugimura, Y., Suzuki, Y. (1988). A high temperature catalytic oxidation method for the determination of non-volatile dissolved organic carbon in seawater by direct injection of a liquid sample. Mar. Chem. 24: 105-131

Suzuki, Y. (1993). On the measurement of DOC and DON in seawater. Mar. Chem. 41:287-288

Tanoue, E. (1992). Vertical distribution of dissolved organic carbon in the north Pacific as determined by the high temperature catalytic oxidation method. Earth Planet. Sci. Lett. 111: 201-216

Toggweiler, J. R. (1990). Diving into the organic soup. Nature 345: 203-204

This review was presented by T. Platt, Dartmouth, N.S. Canada
Toggweiler, J. R. (1992). Catalytic conversions. Nature 356 $665-666$

Toggweiler, J. R. (1993). Carbon overconsumption. Nature 363: $210-211$

Tomi, D. T., Bagster, D. F. (1978). The behaviour of aggregates in stirred vessels. Part I - theoretical considerations on the affects of aggregation. Trans. Inst. Chem. Eng. 56: 1

Tranvik, L. J., Sherr, E. B., Sherr, B. F. (1993). Uptake and utilization of 'colloidal DOM' by heterotrophic flagellates in seawater. Mar. Ecol. Prog. Ser. 92: 301-309

Van Es, F. B., Meyer-Reil, L.-A. (1982). Biomass and metabolic activity of heterotrophic marine bacteria. In: Marshall, K. C. (ed.) Advances in microbial ecology, Vol. 6. Plenum Press, New York, p. 111-170

Van Loosdrecht, M. C. M., Lyklema, J., Norde, W., Zehnder, A. J. B. (1989). Bacterial adhesion: a physicochemical approach. Microb. Ecol. 17: 1-15

Vaque, D., Duarte, C. M., Marrase, C. (1990). Influence of algal population dynamics on phytoplankton colonization by bacteria: evidence from two diatom species. Mar. Ecol. Prog. Ser. 65: 201-203

Wangersky, P. J. (1975). Measurement of organic carbon in seawater. In: Gibb, T. R. P. (ed.) Analytical methods in oceanography. Am. Chem. Society, Washington, DC, p. $148-162$

Wangersky, P. J. (1993). Dissolved organic carbon: a critical review. Mar Chem. 41:61-74

Wells, M. L., Goldberg, E. D. (1991). Occurrence of small colloids in seawater. Nature $353: 342-344$

Wells, M. L., Goldberg, E. D. (1992). Marine sub-micron particles. Mar. Chem. 40: 5-18

Wells, M. L., Goldberg, E. D. (1993). Colloid aggregation in seawater. Mar. Chem. 41: 353-358

Wells, M. L., Goldberg, E. D. (1994). The distribution of colloids in the North Atlantic and Southern oceans. Limnol. Oceanogr. 39: 286-302

Williams, P. J. LeB., Jenkinson, N. W. (1982). A transportable, microprocessor-controlled precise Winkler titration suitable for field station and shipboard use. Limnol. Oceanogr. 27: $576-584$

Williams, P. J. LeB. (1984). A review of measurements of respiration rates of marine plankton populations. In: Hobbie, J. E., Williams, P. J. LeB. (eds.) Activity in the sea IV. Plenum Press, New York, p. 357-389

Williams, P. M., Druffel, E. R. M. (1987). Radiocarbon in dissolved organic matter in the central north Pacific Ocean. Nature 330: 246-248

Manuscript first received: October 20, 1993

Revised version accepted: March 28, 1994 